\title{
HISTORICAL DEVELOPMENT IN THE DOCUMENTATION OF MARRIAGE CONTRACTS
}

\author{
Saad Abdulwahhab Alshekh ${ }^{1}$ \\ Raihanah Hj Abdullah ${ }^{2}$ \\ Mahamatayuding Samah ${ }^{3}$
}

\begin{abstract}
This study investigates the documentation of marriage contracts, beginning from the historical ages of Adam and Eve, peace be upon them, as manifested through the heavenly laws that Allah the Almighty had provided, the laws that were legislated by previous nations before our Prophet Muhammad (PBUH) was sent by Allah followed by the laws decreed by nations after Prophet Muhammad until the Iraqi Personal Status Law. In following the historical process of the documentation of marriage contracts, this study also looks at what was stated in the laws of heaven to see how a marriage contract was established. It looks at the reasons why a marriage contract had certain conditions omitted in the era of the Prophet Muhammad (PBUH), and as according to the Islamic
\end{abstract}

1 Ph.D Candidate, Department of Shariah and Law, Academy of Islamic Studies, University of Malaya, 50603 Kuala Lumpur; Senior Lecturer, University of Baghdad, Baghdad, Iraq, saad_alhaily@yahoo.com

2 Professor, Department of Shariah and Law, Academy of Islamic Studies, University of Malaya, 50603 Kuala Lumpur, raihanah@um.edu.my

3 Lecturer, Department of Shariah and Law, Academy of Islamic Studies, University of Malaya, 50603 Kuala Lumpur, mahyudin@um.edu.my 
law of that period. Specifically, this study aims to understand why Muslims only started documenting their marriage contracts more than two centuries after Hijrah. It also aims to understand what the legitimate policy was, followed by how the marriage contracts and registrations were performed in the Iraqi Personal Status Law. The statements of the contemporary jurists who considered documenting marriage certificates to be the jurisprudence eral nawäzil al-'așr will be analyzed and evaluated. It is hoped that the analysis will be able to highlight the reasons showing why marriage certificates must be documented in accordance with the Islamic law and the civil law.

Keywords: date of marriage contract, marriage contract registration, documenting the marriage contract, religious marriage, jurisprudence era/nawāzil al-'aṣr

\section{INTRODUCTION}

The Shariah law emphasizes the need to stabilize relations in different ways so as to maintain the rights and duties of the people. Among all relations, the one that is most important is the one involving a marriage contract. All contracts are important as has been confirmed by Allah the Almighty and His Prophet, hence the need to document all forms of contracts, including marriages. Former jurists, however, differred in their views on the means of documenting contracts, according to customs and traditions, since some accept verbal contracts while others prefer witnesses. As a result of that, the documentation of contracts made in writing, and by witnesses, was deemed to be the highest level of evidence. This too has been confirmed, as noted in the heavenly books of Abraham, the Torah and the Gospel, beyond the existence of ancient laws. The decline in practice of documenting marriage contracts in writing occurred during the Age of Ignorance although in the beginning of Islam, documentation of marriage contracts through acclamations served to be the highest level of evidence. This was practiced among the Arabs who had been described as people with courage, generosity, honesty, and in telling the truth but who did not know how to read nor write.

The literate Arabs who knew how to read and write only began to document marriage contracts after more than two centuries, after Hijrah. This is evidenced by a set of documented marriage certificates that was confined to the years between $233 \mathrm{AH}$ to $461 \mathrm{AH}$ as well as contracts dating back to the Abbasid era (al-Qahir bi Allah) of between 320AH-322AH, which have been preserved in 
the National Library of Vienna. Additionally, there was also documentation of marriage contracts dating back to the era of the Ayyubids in $904 \mathrm{AH}$. Some of these evidences of marriages contracts can be found in the University of Heidelberg in Germany. ${ }^{4}$ The documentation of the marriage contracts in writing has a great importance in society because it has an influence on the life of the people, the relations' stability, and the respective rights of those married to each other, as can be seen today from the issuance of the fatwas. However, the documentation of marriage contracts made in writing did not exist during the time of the Prophet Muhammad (PBUH), and it was also not mentioned in the al-Qur'ān. Apparently, at that time, marriage contracts were endorsed by witnesses only but as life transcends and evolves, archaic customs and traditions also changed, and people's acceptance of such contracts have also transformed; these possibly also varied among the different tribes, communities, districts and regions. This claim of changes taking place can be traced to some of the references we made to historical marriage contracts which we had analysed and evaluated. We noted that in the past, early nations were interested in documenting marriage contracts in writing as has been revealed in the era of prophecy.

\section{DOCUMENTATION OF THE MARRIAGE CONTRACT BETWEEN ADAM AND EVE, PEACE BE UPON THEM}

Allah the Almighty created Adam, peace be upon him, and from his rib, created Eve, and the Almighty said:

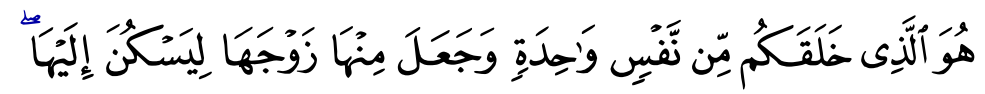

"It is He who created you from a single cell, and from it created its mate, that you may live as companions..."

(Surah al-A'rāf, 7: 189)

The interpretation of this verse states that Allah Almighty, during the sleep of Adam, had created Eve from Adam's rib. When Adam (PBUH) woke up, he asked Eve, 'Who are you?' and she replied, 'A woman, Allah created me for you, so that you may live in me and I dwell in you'. Adam (PBUH) then said,

$4 \quad$ Aḥmad al-Shamī, 'al-Tațawwur al-Tarīkh li 'Uqūd al-Zawāj fī al-Islām,' (Ph.D Thesis, Kulliyyah al-Ādab, Jamī'ah al-Zaqaziq, 1982), 15-16. 
'Oh lord, marry her to me'. ${ }^{5}$ When Adam wanted to extend his hand to Eve, the angels forbade him, and they said, 'You need to give her a dowry'. Adam asked, 'What is her dowry?' and the angels replied, 'Pray on the Prophet Muhammad (PBUH)'. Adam then asked, 'And who is Muhammad?' and the angels said, 'The last of the prophets and messengers'. And when Adam prayed on the Prophet Muhammad (PBUH), Allah Almighty said, 'This is the advance of her dowry, that which keeps on you is the remaining of her dowry' ${ }^{6}$ Thus began the marriage contract between Adam and Eve, peace be upon them. It formed the first marriage contract in history, complete with conditions and pillars, in which the dowry, the witnesses, and guardians were almost identical to the Jewish and Arab sources, which had been witnessed by Allah, and Gabriel, and other angels. ${ }^{7}$

As noted by the author of the book, "Samt al-Nujum al-'Awali fì Anba'i al-Awa'il wa al-Tawali", al-Kisa'i had stated in "Stories of the Prophets", a description, 'When Adam awoke, he was pleased to look at Eve who said to him, 'O Adam, this is maid servant Eve, and she will be with you, and be affable with you', and Adam said, 'O Lord, I want her to be betrothed to me, how shall I get your acceptance?' Allah then said, 'My acceptance is to teach her and yourself religious landmarks'. Adam then said, 'I accepted it, O Lord' and he was, whenever he looked at her, had his feelings of love increased. Allah then said to Adam, 'I created her for you, and you will marry her with my covenant and my charter'. Henceforth, Allah commanded Gabriel to be the suitor, and the Lord of all the worlds, the guardian, and the testimony

5 Abī Bakr 'Uthmān Muḥammad Shața' al-Dimyatī al-Bakrī, I'ānah al-Ṭālibìn 'ala Hal Alfāz Fath al-Mu in, vol. 3 (Bayrūt: Dār al-Fikr li Ṭaba'ah wa al-Nashr wa al-Tawzī‘, 1997), 396; Abū al-Fidā', Ismā'īl Haquī bin Mușțâa al-Istanbūlī alḤanafī al-Khalūtī, Rūḥ al-Bayān, vol. 1 (Bayrūt: Dār al-Fikr, n.d.), 442.

6 Al-Naysābūrī, Niz̄ām al-Dīn al-Ḥasan bin Muḥammad bin Husayn al-Qamī, Gharā'ib al-Qur'ān wa Raghā'ib al-Furqān, vol. 1 (Bayrūt, Lubnān: Dār alKutub al-'Ilmiyyah, 1996), 254; Al-Ilbiri known as Ibn Abī Zamānin al-Malikī, Abū 'Abd Allāh Muḥammad bin 'Abd Allāh bin 'Īsā bin Muḥammad al-Marri, Tafsīr al-Qur'ān al- 'Azīz li Ibn Abī Zamānin, vol. 2, taḥqīq Abū 'Abd Allāh Ḥusayn bin 'Uqashah (Qāhirah, Miṣr: Muḥammad bin Mușțafā al-Kanz al-Faruq al-Hadīthah, 2002), 158.

7 Ibrāhīm Zakī Khurshīd, Aḥmad al-Shantanāwī, 'Abd al-Ḥamīd Yūnus, Mūjaz Dā'irah al-Ma'ārif al-Islāmiyyah, tarjamah Nukhbah min al-Asātidhah alJāmi 'āt al-Mișriyyah wa al-'Arabiyyah, al-Murāja'ah wa al-Ishrāf al-'Ilmī, vol. 14, Ḥassan Habashī, 'Abd al-Rahmān 'Abd Allāh al-Shaykh, Muḥammad 'Annān̄̄ (Markaz al-Shāriqah li al-Ibdā‘ al-Fikrī, 1998), 4428.

8 Al-Kasānī, Muḥammad bin 'Abd Allāh, Qaṣaṣ al-Anbiyā', taṣḥ̄ị Isḥāq bin Saul Izinberg, vol. 1 (Leiden: Maṭba'ah Barbil, 1922), 33. 
of the angels, and Allah said to Adam, 'Bring me Eve's dowry', and Adam said, 'What is her dowry?' and Allah said, 'You need to glorify me a thousand praises in one say'. Thereupon, Adam glorified five hundred glorifications and stopped. Allah Almighty then said to Adam, 'This is the expedited and the rest will be her delayed dowry'. ${ }^{9}$ When Allah Almighty said, 'My covenant and my charter', they served as evidence of the first documentation of marriage preserved in tablet, the marriage of Adam and Eve. Therefore, this can be considered the committed and completed marriage as Allah Almighty said in the al-Qur' $\bar{a} n$ :

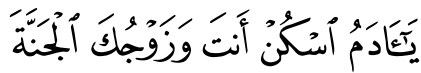 \\ "O Adam, dwell with your mate in paradise,"}

(Surah al-Baqarah, 2: 35)

As a matter of interpretation, the question then arises, 'Was there any written marriage contract between Adam and Eve?' Searching for evidence, this paper did not find a hadīth qudsī, a prophetic hadīth, or any Quranic verse that could be said as indicating a written marriage contract between Adam and Eve. Although the Quranic verse, 'O Adam, dwell with your mate in paradise` may be interpreted as indicating an existence of a marriage contract between them, it could not be further verified except based on what was written as a marriage contract between Adam and Eve, as noted in the preserved tablet, and also through the testimony of the angels.

According to the hadīth qudsī, when Adam (PBUH) gave forty years of his own age to his son, David, the event was documented by Allah, and witnessed by angels. ${ }^{10}$ It seems that during this time, witnesses and writing were synonymous to each other, supporting each other to the point that Adam (PBUH) would not forget what he had given to his son, David. This event was written by Allah Almighty in the preserved tablet, and the angels stood as witnesses so that Adam (peace be upon him) would not be able to deny it. In the hadìth of the Prophet Muhammad (PBUH), it was mentioned, 'The first

9 Al-Makkī, 'Abd al-Mālik bin Ḥusayn bin 'Abd al-Mālik al-'Ișāmī, Samt al-Nujūm al- 'Awālī fì Anbā' al-Awā'il wa al-Tawālī al-Mutawaffā, vol. 1, taḥqīq 'Ādil Aḥmad 'Abd al-Mawjūd, 'Alī Muhammad Mu'awwad (Bayrūt: Dār al-Kutub al'Ilmiyyah, 1998), 88.

10 Al-Shaybānī, Abū 'Abd Allāh Aḥmad bin Muhammad bin Hanbal bin Hilāl bin Asad, Musnad al-Imām Aḥmad bin Hanbal, vol. 4, ed. Shu'ayb al-Arna'ūṭ (n.p.: Mu'asasah al-Risālah, 2001), 128, hadīth raqm 2270, isnaduhu șahīh. 
person who denied is Adam (PBUH), he said it three times'..$^{11}$ The wisdom of Allah Almighty to write that event in the preserved tablet is a lesson for human beings, to teach human beings to write, document and codify what happened. Allah Almighty has all the qualities, Allah is free from error, and forgetfulness, yet Allah preserved in tablet what Adam had given to his son, for wisdom purposes.

This study notes that a dowry was mentioned between Adam and Allah for Eve, peace be upon them, as well as the existence of a marriage contract that existed due to the presence of the angels who stood as witnesses. Although the marriage contract was not explicitly described in the al-Qur'ān, it was nevertheless, written in the preserved tablet, and this was clearly based on the words of Allah Almighty who had it written down when Adam delivered his age to his son David. This too was witnessed by the angels. As Allah Almighty documented everything in the preserved tablet, Allah said:

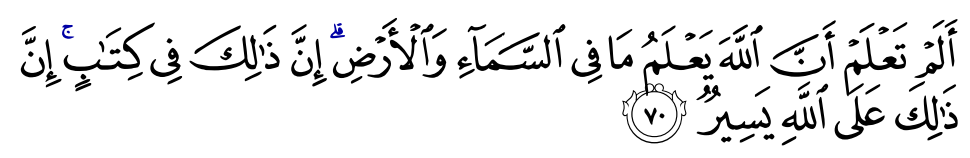

"Do you know that Allah knows whatever there is in the heaven and the earth? All that is in Book. That is indeed easy for Allah..."

(Surah al-Hajj, 22: 70)

By the above, Allah means the book of the preserved tablet. ${ }^{12}$ Following the verse of Allah, we know that Allah also said:

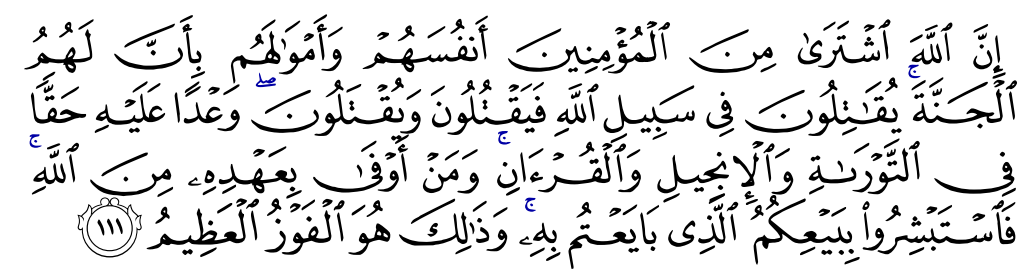

"Indeed Allah has bought from the faithful their souls and their possessions for paradise to be theirs: the fights in the way of Allah, kill, and are killed. A promise binding upon him in the

$11 \quad$ Al-Shaybān̄̄, Abū 'Abd Allāh Aḥmad bin Muḥammad bin Ḥanbal bin Hilāl bin Asad, Musnad al-Imām Ahmad bin Hanbal, vol. 5, 463.

12 Muḥammad bin Yusuf known as al-Andalūsī Muḥammad bin Yūsuf Abū Ḥayyan, Tafsīr al-Bahrr al-Muḥịt, vol. 6, taḥqīq al-Shaykh 'Adīl Aḥmad 'Abd al-Mawjūd alShaykh 'Alī Muhammad Mu'awwad (Bayrūt, Lubnan: Dār al-Kutub al-'Ilmiyyah, 2001), 233. 
Torah and Evangel and the al-Qur'ān. And who is truer to his promise than Allah? So rejoice in the bargain you have made with Him, and that is the great success..."

(Surah al-Tawbah, 9: 111)

Allah Almighty also ordered the worshippers to write a loan and to testify to it, and Allah said in the al-Qur'ān:

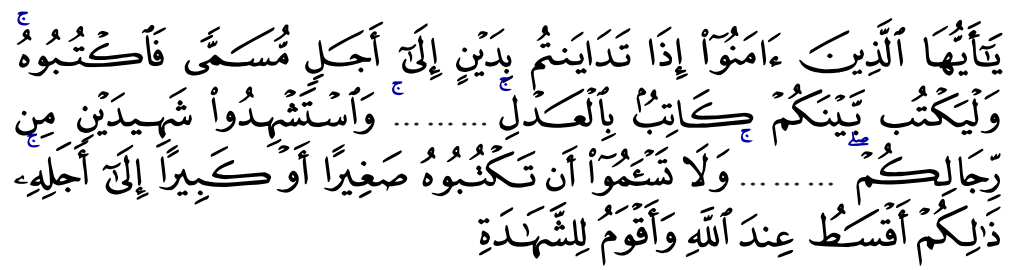

"O you who have faith! When you contract a loan for a specified term, write it down, let a writer write with honesty between you........ and take as witness two witnesses from your men..... and do not consider it wearisome to write it down, whether to be a big or small sum until its term. That is more just with Allah and more upright in respect to testimony..."

(Surah al-Baqarah, 2: 282)

Allah Almighty also wrote an allegiance that took place between Him and the worshippers, and the witnesses who were made up of the angels. Based on the al-Naysābūrī, Allah the Almighty said:

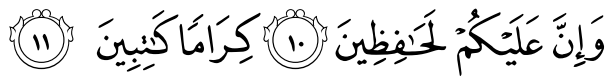

"Indeed, there are over you watchers, noble writers..."

(Surah al-Infițār, 82: 10-11)

And as Allah Almighty ordered us to write religion and allegiance, whether small or large, so too do the angels who write everything. ${ }^{13}$ Allah created the pen to teach people to write, and to document everything, whether marriage contracts, transactions or science documentations. In the hadith, the Prophet Muhammad (PBUH) said:

13 Al-Naysābūrī, Niẓām al-Dīn al-Ḥasan bin Muḥammad bin Husayn al-Qamī, Gharā'ib al-Qur'ān wa Raghā'ib al-Furqān, vol. 2, 81; Abū Hafs Sirāj al-Dīn 'Umar bin 'Ali bin 'Ādil al-Ḥanbal̄̄ al-Dimashq̄i al-Nu'mān̄̄, Allubāb fì 'Ulum al-Kitāb, vol. 20, taḥqīq al-Shaykh 'Ādil Aḥmad 'Abd al-Mawjūd wa al-Shaykh 'Alī Muḥammad Mu'awwad (Bayrūt: Dār al-Kutub al-'Ilmiyyah, 1998), 111. 


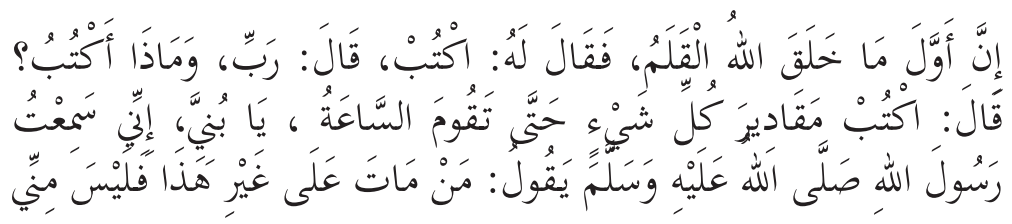

"The first thing Allah created is the pen, he said to him: Write, he said: Lord, and what do I write? He said: Write everything until hours of resurrection" O my son, I have heard the messenger of Allah peace be upon him says: "Whoever dies and not following this he is not from me." 14

This study reasons that destiny has four levels: science, writing, will, and creation. Accordingly, the rank of writing comes in the second place of the order of destiny, and this refers to the belief that Allah wrote the destiny of all creatures in the preserved tablet, and the angels then wrote by Allah's order. ${ }^{15}$

\section{DOCUMENTATION OF THE MARRIAGE CONTRACTS MADE IN THE LAWS OF HEAVEN}

In the Book of Torah, we find evidence which certifies that the writing of the marriage contract was completed in two formal stages, and that the marriage contract was written and certified. From the first stage, the religious stage, the marriage contract requires a prayer, and this prayer is known as seven blessings. ${ }^{16}$ This practice appears in the Jewish religion which acquired its legislation from the Bible, the Torah and the Talmud, where the prayer is expressed by the Rabbis. Marriage in the Talmud passes through three stages:

Stage one is sanctification, which means that the marriage is expressed in the sermon, which is the man's proclamation to approach a particular woman.

14 Abū Dāwud, Sunan Abū Dāwud, vol. 4, taḥqīq Muḥammad Maḥy al-Dīn 'Abd alHamīd (Bayrūt: al-Maktabah al-'Așriyyah, Duna Dhakara Sanah al-Nashr, 1965), 362, ḥadīth raqm 4720, "Bāb fī al-Qadr”; Ibn al-Āthīr, Majd al-Dīn Abū al-Sa'ādāt al-Mubārak bin Muḥammad bin al-Āthīr al-Jazarī, Jāmi ' al- 'Ușūl fì Ahāàìth alRasūl, vol. 10, taḥqīq 'Abd al-Qādir al-Arna'ūṭ al-Tatimmah, taḥīiq Bashīr Muhammad 'Uyūn (n.p.: Maktabah al-Halwān̄̄, Maṭba'ah al-Malāḥ, Maktabah Dār al-Bayān, 1972), 107.

15 'Abd al-'Azīz al-Muhammad al-Salman, Mukhtașșar al-Așilah wa al-Ajwibah al- 'Ușūliyyah 'ala al-'Aqīdah al-Wașațiyyah (n.p.: Dūn al-Dikr Makān al-Tibā', 1997), 121.

16 Zirar, Malikah Yūsuf, Mawsū 'ah al-Zawāj wa al- 'Alaqal al-Zawjiyyah fì al-Islām wa al-Sharā'i 'al-Ukhra al-Muqāranah, vol. 1 (Qāhirah, Mișr: Dār al-Ghurayb li al-Ṭaba'ah, 2000), 67. 
Stage two is the writing of the contract which in Hebrew is called Ketubah. The articulation of this contract involves the dowry, the witnesses, the marriage conditions, and the contradiction statement.

Stage three is where the holy prayer is recited as a meeting is conducted, and where the marriage contract is pronounced. ${ }^{17}$

All these three stages of the marriage contract were also noted in the Book of Tobiah 7 verse 16, 'Then they took a newspaper, and wrote the marriage contract'. In verse 17, the versed added, 'Then eat and bless God'. This verse was mentioned in the book of the Torah as a plural form, 'And then they took a manuscript and wrote the marriage contract, the marriage contract was written by witnesses'. In other words, a marriage is a feast and a declaration (and then blessed by God), followed by a prayer of seven blessings. It appears that even as a marriage contract was being documented, so too were divorces.

In the Book of Deuteronomy 22/13, it was written, 'If a man takes a wife, and after sleeping with her, dislikes her', was a preface to the divorce because in the continuation of Deuteronomy $1 / 24$, it was stated, 'and writes a divorce book, gives to her and divorces her from his house' became the evidence showing that divorce was stated in the Bible, and that, just as a marriage, a divorce also requires documentation. In this regard, it was clear that the Jewish law was also interested in having a contract over the issue of money and funds. It was observed that the Jews also have in writing, a sales and purchase contract to certify their transactions.

In the Book of Jeremiah 32/10, it was written, 'I signed and sealed the deed, had it witnessed, and weighed out the silver on the scales' to show a written contract for a financial transaction.

Similarly, in Verse 11, it was stated, 'I took the purchase agreement, the sealed copy with its terms, conditions, and the open copy'.

In Verse 12, it was written, 'I handed over the purchase order to Baruch the son of Neriah, the son of Mahaseh, before Hennamiel, my cousin, and before the witnesses who had taken the deed of purchase before all the Jews who were sitting in the prison house'.

In Verse 44, 'they buy the fields with silver, and they write this in sukuk (bonds), and seal and witness witnesses, they took care of their money for their immense love of the money'.

17 Millar Burrows, Louis M. Epstein, 'Marriage Laws in the Bible and the Talmud,' Journal of Near Eastern Studies, vol. 3/2 (1944), 104-105. 
After the Book of Torah, Allah Almighty revealed to Jesus, peace be upon him, the Book of Gospel, which is called the New Testament. As can be noted, the Bible relates to spirituality without transactions and relations, but the people of the Gospel depended on the contained provisions in the Torah, as told to us by Allah Almighty:

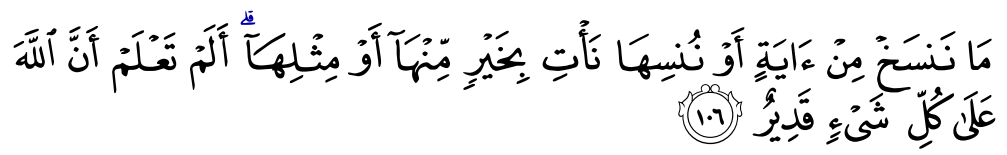

"When we cancel a message (sent to an earlier prophet) or throw it into oblivion: [We replace it with one better or one similar. Do you not know that God has power over all things?"

(Surah al-Baqarah, 2: 106)

Allah Almighty copied some verses which did not correspond with the time of the Prophet Jesus, and Allah Almighty kept some of these verses which comprised the marriage contract, the sanctity of murder, adultery and others. ${ }^{18}$ In the absence of the marriage provisions noted in the Bible, the church clergy had set up some rules for the marriage contract, which subsequently, became the religious rules due to their long-standing application.

The first stage of marriage in Christianity begins with a sermon, which is a contract between two persons who have the formal conditions prescribed by the church. After the checking of their age, and if there was no objection between them, then there is consent to complete the marriage contract. The second stage of marriage in Christianity is the observation of the religious condition which is performed before the church priests. The Christians agree that their marriage contract can only be done during the presence of a cleric, and the prayer of the wreaths before the offering of their sacrifice to each other. The prayer before the cleric can be considered as the completion of the marriage contract whereby the union of two persons becomes one body. Thus, this marriage contract must be documented in public. ${ }^{19}$

18 Ibn 'Āshūr, Muhammad al-Ṭāhir bin Muhammad al-Ṭahir, al-Tahrīr wa al-Tanwīr, vol. 1 (Tunisiyah: Dār Saḥnūn li Nashr wa al-Tawzī‘ , 1997), 657.

19 Muḥammad Shukrī Surūr, Niz̄ām al-Zawāj fì al-Sharā' 'i al-Yahūdiyyah wa alMasīḥiyyah (Miṣr: Dār al-Fikr al-'Arabī, 1979), 131. 


\section{DOCUMENTATION OF MARRIAGE CONTRACTS IN THE OLD IRAQI LAWS}

In this study, Iraq is taken into account as the cradle of ancient civilizations where it housed the first city, and served as the civilizational centers that were established and developed in which the first human attempt was made to write and legislate laws. ${ }^{20}$ Some features of the ancient laws seen in Iraq are the validity and legitimacy of marriages. Previous laws in Iraq did not recognize the marriage contract unless the contract was registered and attested, ${ }^{21}$ coupled by an oath from both parties in front of the King and the Gods. This is necessary so as to comply with the terms of the contract, such as to include the names of the witnesses in the contract board, and the conclusion date. ${ }^{22}$ The marriage contracts were documented in the old Iraqi laws, such as the law of Ornmo and Ashuna, the Assyrian laws, and the Hammurabi. In this study, we present these laws with the date of their rules of ancient Iraq, according to the reverse calendar year.

Article (8) of the law of Arnmo, which ruled old Iraq in the year 2112-2095 $\mathrm{BC}$ stated that, 'If the man slept with the widow without a marriage contract, he does not need to pay anything in the case of a divorce' ${ }^{23}$ As written in the marriage contract in the law of Ashuna, which ruled old Iraq in the year 1924 - $1924 \mathrm{BC}$, the marriage contract is to be written in the presence of God and witnesses.

In Article (27), 'If a man marries a woman without the approval of her father and mother, does not have the wedding feast and does not contract with her father and mother, then this woman will not be a wife even if she lived in his house for a whole year'. This evidence showed that the marriage contract consists of a guardian, witnesses, and a feast, and the marriage contract here mentioned here pointed to the documented contract that was done according to the religious form of God. ${ }^{24}$

20 Radinah Muhammad Rida Majīd, al-Ahwāl al-Shakhșiyyah fì al-Qawānīn al'Irāqiyyah al-Qadīmah ('Iraq: Majallah Markaz Dirāsah al-Kufah, 2011), 258.

21 Țaha Baqir, Muqaddimah fì Tārīkh al-Hadarāt al-Qadīmah, vol. 1 (Baghdād: Sharīkah al-Tijārah wa al-Tibā'ah, 1965), 408.

22 Șabīḥ Maskūnī, Tārīkh al-Qānūn al- 'Irāqū al-Qadīm (Baghdād: Maṭba'ah Shafĩq, 1971), 180.

23 Thalmā Sityān 'Aqrāwī, al-Mar'ah: Dawruhā wa Makānatuha fì Hadāarah Wād̄̄ al-Rāfidayn (al-Baghdād: Dār al-Hurriyyah li al-Tibā'ah, 1978), 289.

24 Aḥmad Hāshim Ibrāhīm al- 'Aț̣āar, 'Huqūq al-Mar'ah fĩ al-Sharā'i' al-'Irāqiyyah al-Qadīmah,' Silsilah Thaqāfiyyah Shahriyyah tașdur 'an (Baghdād: Dār alShu'ūn al-Thaqāfiyyah al-'Āmmah, 2010), 43. 
The first book of the Assyrian laws referred to the marriage contract in Article (36), 'If the king sends a married man to another country and he spends more than five years, then his wife should respect him and do not go to live with another man. If the wife had intercourse with another man before the end of the five years, and had given birth to children, her husband (the first) has the right to return his wife and children because she did not respect the marriage contract as she remarried'.

Article (41) of the same law provides for the public marriage contract which states, 'If a man wants to put the veil due to confidentiality, he should call five or six of his friends. He puts the veil on her in front of them saying, "This is my wife". The secrecy of this statement is considered the legitimate wife'.

As for the confidentiality that was not concealed before the witnesses, and where the husband did not say about her, "This is my wife", she is not a legitimate wife, but remains a secrecy. If the man dies, and his veiled wife does not have children, the children of the secrecy are considered his heirs' ${ }^{25}$

Hammurabi who ruled Iraq from the year 1750-1793 BC mentioned in Article (128), 'If a man takes a woman to wife, but has no intercourse with her or does not draw up a marriage contract, this woman could not be his wife'. By contract, Hammurabi was referring to the oldest written marriage contract of the year $365 \mathrm{BC} .{ }^{26}$ which was recognized by historians.

Hammurabi had collected the legal texts that preceded his ruling, and then turned them into this obelisk. Some of these laws were taken from the manuscript that came from our Prophet Ibrahim, especially those relating to personal status. ${ }^{27}$

In general, authentication of a marriage with a certification was mentioned in the contracts in the old legal laws, such as the law of Asuna, the law of Ishtar, the law of Armor as well as the laws that preceded them where King Hammurabi ${ }^{28}$ had collected those laws, omitted what did not match with his rule of the old Iraq, and then included all these laws including all aspects of

25 Aḥmad Hāshim Ibrāhīm al-'Aț̣āar, 'Huqūq al-Mar'ah fī al-Sharā'i' al-'Irāqiyyah al-Qadīmah,' Silsilah Thaqäfiyyah Shahriyyah tașdur 'an, 319-320.

26 Aḥmad al-Shamī, 'al-Tațawwur al-Tarīkh li 'Uqūd al-Zawāj fĩ al-Islām,' 14.

27 Hukm Hammurabī bayn (1793-1750) BC,wa hasb ma wasalna 'an Tarīkh Sayyiduna Ibrahim 'alayh al-salam bi hudūd (1850); Al-A'ẓamī, Muhammad Ṭaha Muḥammad wa Aḥmad Majīd Hamīd, Qānūn Hammurābī Dirāsah Muqārinah (Iraq,Majallah al-Najaf al-Ashraf, al-'Adad al-Awwal 2003), 10.

28 Muștafā Faḍ̄i Karīm al-Khafajī, Majallah Markaz Babil li al-Dirāsah alInsāniyyah, Majallah 3, ed. 2, Tarikh al-Qānūn fĩ al-Mujtamat al-Qadimah (Qānūn Hammurabi Anamudhaj), 290. 
life, into the obelisk (282), during his reign between 1750-1793 BC. Several of the articles in the obelisk had stated the documentation of a certificate and writing in the contract, specifically in Hammurabi's code of law, Article (7), 'If anyone buys from the son or the slave of another silver or gold, a male or female slave, an ox or a sheep, an ass or anything, (without witnesses or a contract)... or if he agrees to take charge of stolen property, he is considered a thief and shall be put to death'.

In this text, it was shown that Hammurabi treated the sale without witnesses or in writing as a treatment of the thief. This was to enable him to maintain the stability of the transactions, fearing immorality and denial. In this study, we also noted that there was a correlation between writing with attestations in several legal texts in Hammurabi, for example, Articles (104), (122), and (123), which all stated the writing of the contract, and the certificate.

Article (104), 'Anyone delivers to a middleman, factor or broker, grains, sesame or other merchandise to sell [for his account], the middleman, factor or broker, shall give him a receipt or a written obligation setting forth the commission, and the conditions [contract of brokerage] under which sales and disposals of the properties are to be made, and shall, in return, take a receipt [a written authority to sell] from his consignee. The middleman, factor, or broker, shall not use the money of his business man [consignee] unless receipted for [authorized in writing]." Here, the loan and sale between traders was confirmed by a stamp sealed between them and witness testimony. This served as an evidence of the evolution of their lives, and the existence of a seal at that time.

In Article (122), 'If anyone delivers gold, silver or other personal property for safe-keeping, he shall exhibit the articles to be stored to a witness, and thereby close the contract for safe-keeping'. Here, too, the deposit was being written in considering that the deposit was a type of contract, hence, the depositor must write the deposit and confirm with the witness. The supplement of the text in Article (123), 'If he hands it over to the governorate without witnesses and contracts, and they deny receiving it, this complaint is unaccepted'. The law of Hammurabi proved that a lawsuit was not started if there were no written contract, and so this evidence served as the strength of the state's justice at that time. 


\section{DOCUMENTATION OF MARRIAGE CONTRACTS IN THE ERA OF THE PROPHET MUHAMMAD (PBUH)}

Before Allah Almighty sent our Prophet Muhammad (PBUH), the marriage contract noted in the Arabs Al Ignorance age was of four types. One of them was what people are doing today, the man asks for the woman's hand from her guardian, document the act, then marry her. The other types of marriage were incorrect. When Allah Almighty sent our Prophet Muhammad (PBUH), marriage in the pre-Islamic era had been omitted, except for the marriage of the Muslims, similar to today. ${ }^{29}$ The marriage of Muslims according to Islam is as stated in the hadith - No marriage except with the existence of a guardian and two trusted witnesses. ${ }^{30}$

The documentation of a marriage contract was not established in writing during the time of our Prophet Muhammad (PBUH) because the Arabs of alJahiliyah in the early days of Islam, had not mastered the skill of reading and writing, hence they did not know how to read and write. This was noted in the first Surat in the al-Qur'ān which revealed the teaching of the Prophet to read the words of the Almighty:

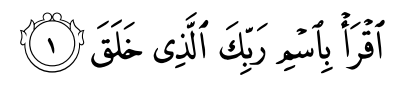

"Read in the name of your Lord who created..."

(Surah al-‘Alaq, 96: 1)

This verse encourages the followers to learn and read. It was stated in the explanation that the Prophet Muhammad (PBUH) did not know how to read. During the revelation, he was told to say (READ) many times, and the prophet said, 'What am I reading?' It was revelation that taught him how to read even though he did not know writing, ${ }^{31}$ and this evidence confirmed the illiteracy of the Arabs, just as Allah Almighty had said:

29 Al-Bukhārī, Șaḥ̄h al-Bukhārī, vol. 7, taḥīi Muḥammad Zuhayr Ibn Nāṣir alNāṣir (Dār Ṭūq al-Najāh, 1422H), 15, ḥadīth raqm 5127.

30 Al-Bayhaqī, al-Sunan al-Kubrā, vol. 7, taḥqīq Muhammad 'Abd al-Qādir 'Ațā (Bayrūt: Dār al-Kutub al-'Ilmiyyah, 2003), 181.

31 Al-Qāsimī, Muḥammad Jamāl al-Dīn bin Muhammad Sa‘īì bin Qāsim al-Hallāq, Maḥāsin al-Ta'wīl, vol. 9, taḥqīq Muḥammad Bāsil 'Uyūn al-Sūd (Bayrūt: Dār al-Kutub al-'Ilmiyyah, 1418H), 507. 


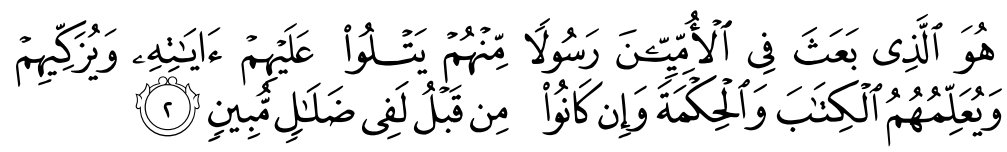

"It is He who raised among the gentiles an apostle from amongst them, who recites His revelations, reforms and teaches them the Scripture and the Law, for before him, they were clearly in error.."

(Surah al-Jumu'ah, 62: 2)

In the interpretation of the verse, it was mentioned that the illiterate Arabs do not read or write. When the Almighty said, 'amongst them', he means among them is an Arab like them who was intended to be Muhammad (PBUH). This interpretation of the verse does not mean that all the Arabs were illiterate because among them, there were some who knew how to read and write, one of whom was Handala, the only writer.

Writing had started with Mu'awiyah Ibn Abī Sufyan and Zayd Ibn Thābit, who were writing to the Prophet Muhammad (PBUH).

It is said that writing started in Tầ'if, and it originated from the people of alHira (a town near Kufa in Iraq), and the people of al-Hira who had learned the art of writing from the people of Anbar (an ancient city on the Euphrates River in Iraq and it is now one of the provinces of Iraq). ${ }^{32}$ The Prophet Muhammad (PBUH) had indicated that the Arabs were an illiterate nation in the hadìth:

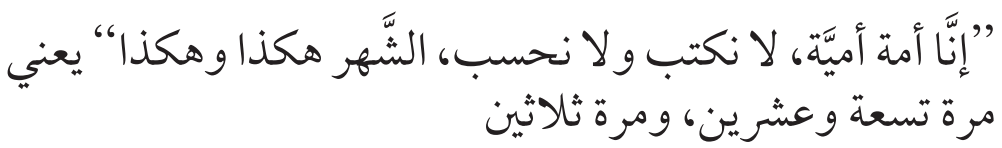

"We are an illiterate nation, we do not write or count, the month is so and so "It means twenty-nine times, thirty times". ${ }^{33}$

The statement above was one of the causes that led to the disagreements of the scholars such as the Hanafi, Shaafi, Maliki and Hanbali ${ }^{34}$ when examining

32 Al-Hafī, Muḥammad al-Amīn bin 'Abd Allāh al-Aramī al-'Alawī al-Hararī, Muraja at, Hashim Muhammad 'Alī bin Husayn Mahdī, Tafsīr Hada'iq al-Rūh wa al-Rayḥān fì Rawābi ' 'Ulūm al-Qur'ān (Bayrūt, Lubnan: Dār Tawq al-Najah, 2001), 29, 285, 286.

33 Al-Bukhārī, Șahīh al-Bukhārī, vol. 3, "Kitāb al-Ṣawm, Bāb Qawl al-Nabī șalla Allāh "alayh wa sallam "la naktub wala nahsub," 28, ḥadīth raqm 1913.

34 Al-Sarakhsī, al-Mabsūț, vol. 8 (Bayrūt: Dār al-Fikr li al-Ṭabā'ah wa al-Nashr wa al-Tawzī', 2000), 25; al-Dubyān, Abū 'Umar Dubyān bin Muhammad, alMu 'āmalah al-Māliyyah Așālah wa Mu'āsirah, vol. 18 (Riyāḍ: Maktabah alMālik Fahd al-Watāniyyah, 1432AH), 305. 
the authority of writing in the various transactions and relations of the documents.

\section{The Malikis and the Hanbalis ${ }^{35}$}

The Hanafis, some of the Shaafis, the Malikis and the Hanbalis thought that the writing aspect of the contract was easy to falsify because it was possible to mimic the handwriting, but at the same time, it was also necessary to prove a transaction with certification in writing. ${ }^{36}$ The Malikis, and some of the Hanbalis responded to those who thought this to be true by saying that, 'It was easy for experts to recognize the fraud because they can detect fraudulent writings' ${ }^{37}$ but certifications by witnesses were not always reliable because they were also subjected to forgetfulness as well. The Hanafis, some of the Shaafis, the Malikis and the Hanbalis also thought that writing as a means of prove of evidence for a contract, was a heresy since it was not mentioned in the holy al-Qur'ān, which had instead, stated the use of witnesses, and other proof methods such as testimony, oath, endorsement, and refusal to take the oath. ${ }^{38}$ In this regard, the Malikis, and some of the Hanbalis responded with an adopted opinion, 'Allah Almighty ordered writing, but the scholars' diverged in the obligation due to a lack in writing'. However, this does not mean that the authoritative writing is a heresy. ${ }^{39}$ Allah Almighty ordered the writing and the testimony so as to increase the strength of the documentation for it to be inferred by writing alone, if there was no suspicion and the instrument of proof was not one of worship.

In the observation of marriage contracts in Islam, it can be said that Islam is not the religion of formalities to be limited to what is stated in the texts. It is possible to use contemporary ways as evidence of proof, hence writing could not be considered a heresy. Writing is one way to reach the purposes of the

35 Al-Zuhaylī, Muhammad Mușțafā, Wasā'il al-Ithbāt, vol. 2 (Dimashq: Dār alBayān, 1982), 423.

36 Abī Muḥammad 'Abd Allāh Ibn Aḥmad Ibn Muḥammad Ibn Qudāmah al-Maqdisī, al-Kāfì fì al-Fiqh al-Imām Aḥmad, vol. 4 (Bayrūt: Dār al-Kutub al-'Ilmiyyah, 1994), 244.

37 Al-Ya'murī, Ibrahim bin 'Alī bin Muhammad bin Farhūn, Burhān al-Dīn, Tabṣīrah al-Hukkām fì 'Ușūl al-'Aqdiyyah wa Manāhij al-Ahkām, vol. 1 (Miṣr: Maktabah al-Kulliyyah al-Azhariyah, 1986), 440.

38 'Ārif 'Alī 'Ārif al-Qaradaghī, 'Silsilah Buhūth al-Fiqhiyyah fì al-Qaḍāyā alMu'āsirah,' Masā'il Shar 'iyyah fì Qad̄ayā al-Mar'ah (Malaysia: al-Jamī'ah alIslāmiyyah al-'Alāmiyyah, 2010), 38.

39 Al-Zuḥaylī, Muḥammad Muștafā, Wasā’ il al-Ithbāt, vol. 2, 426 
Islamic laws, and to achieve one's right. ${ }^{40}$ The Hanafis, some of the Shaafis, the Malikis and the Hanbalis thus inferred, 'It is not authentic to write without a certificate of the Holy al-Qur'ān as the Almighty said:

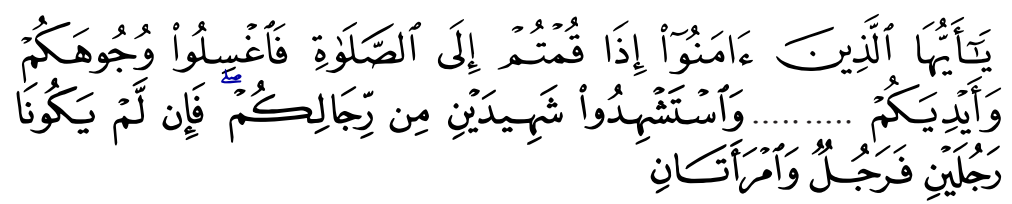

"O believers, when you negotiate a debt for a fixed term, draw up an agreement in writing..... and have two of your men to act as witnesses, but if two men are not available, then a man and two women.."

(Surah al-Baqarah, 2: 282)

By this, the al-Qur' $\bar{a} n$ has thus endorsed the writing with the certification, therefore, it is not permissible to accept a writing that was authenticated without a certification.

In addition, the Malikis and some of the Hanbalis responded with an adopted opinion, 'The scholars' divergence between obligation and the lack in writing, whatever the writing verdicts, can be referred to the verse which guides it'. If there were no protest on writing, Allah Almighty would not have mentioned it in the holy al-Qur'ān. The testimony in writing was only for the purpose of supporting the documentation; it is possible to use the writing as an argument in cases of dispute. ${ }^{41}$ In this study, we reason that every statement has its argument. Nonetheless, the reason for the differences which diverged from our viewpoint may be attributed to several causes, including the differences in the interpretations of the Ayat Addain.

The Hanafis, some of the Shaafis, the Malikis and the Hanbalis thought of accepting the whole verse without separation. They mentioned that it was not authentic to write without witnessing. The opinion was adopted by the Malikis while some of the Hanbalis accepted the separation of the first part from the second part of the verse. However, as what had been normal during their era, certification was accepted to be more credible than writing. The people's customs at that time was for the presence of the witness as this was then considered to be the highest proof of evidence. This situation

40 'Ārif 'Alī 'Ārif al-Qaradaghī, 'Silsilah Buhūth al-Fiqhiyyah fĩ al-Qaḍāyā alMu'āsirah,’ 39.

41 Al-Zuhaylī, Muḥammad Muștafā, Wasā’ 'il al-Ithbāt, vol. 2, 423. 
was inevitable at that period of time because the people were still illiterate, unable to read nor write. Moreover, their action or practice of doing so was in accordance with the Islamic rules of law. The Arabs, during that period of history, were known for their courage, generosity, and honesty; they also held strong religious beliefs and fear of Allah's wrath, hence transactions tended to be simple. Further, it was normal for the neighbors to know each other or other neighbors since everyone who lived in the village or city were familiar to each other. It has been insisted by some researchers that writing is a necessity as it can be used together with the witness for disputes later on. Sometimes, such proofs may also require the witness in writing although sometimes contracts were accepted in writing without a witness as proof of argument.

\section{REASONS FOR NOT DOCUMENTING MARRIAGE CONTRACTS IN WRITING IN THE TIME OF THE PROPHET (PBUH)}

Before Islam, the Arabs were embraced in a period of ignorance. This was the historical era after the Prophet Jesus (PBUH), at a time when all Islamic laws were not revealed yet until the arrival of the Prophet Muhammad (PBUH). Allah Almighty had then said:

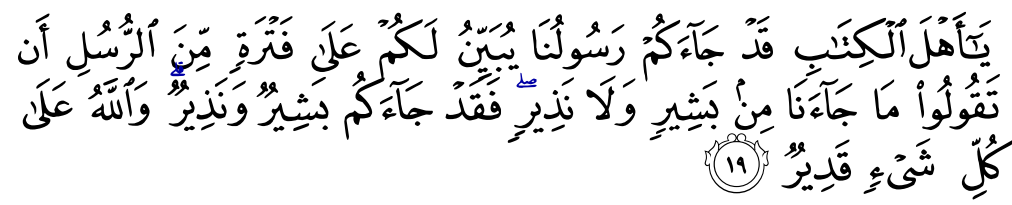

"O people of the Book, Our Apostle has come to you when apostles had ceased to come long ago.."

(Surah al-Mā'idah, 5: 19)

In the period between the last Prophets of the Children of Israel, Jesus, (PBUH), and the Prophet Muhammad (PBUH), there was divergence between the Tafseer of Althalabi, and the hadith scholars. ${ }^{42}$ This was in the period of six hundred years, as quoted from Șahīh al-Bukhāri, ${ }^{43}$ or five hundred and ninety-

\footnotetext{
42 Al-Tha'labī, Abū Zayd 'Abd al-Raḥmān bin Muhammad bin Makhlūf, al-Jawāhir al-Hisān fì Tafsìr al-Qur'ān, vol. 2, taḥqīq al-Shaykh Muhammad 'Alī Mu'awad wa al-Shaykh 'Ādil Aḥmad 'Abd al-Mawjūd (Bayrūt, Lubnān: Dār Ihyā' al-Turāth al-'Arabī, 1418H), 367.

43 Al-Bukhārī, Șaḥ̄ḥ al-Bukhārī, vol. 3, ḥadīth raqm 3732.
} 
nine years as noted in the Tafsir of al-Qasimi ${ }^{44}$ and five hundred and forty-six years as cited in the Tafsīr of Rüh al-Bayān. ${ }^{45}$

This period of almost six centuries was a dark period in the life of mankind because ignorance, injustice, and gloominess were widespread. Allah Almighty had said:

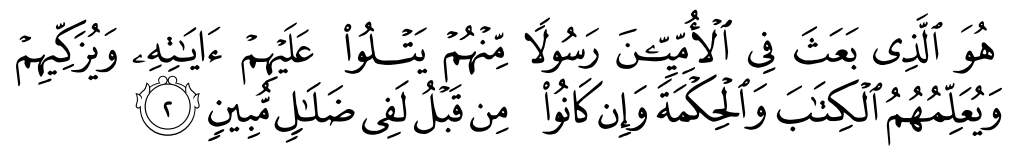

"It is He who raised among the gentiles an apostle from amongst them, who recites His revelations, reforms and teaches them the Scriptures and the Law, for before him they were clearly in error.."

(Surah al-Jumu'ah, 62: 2)

People of that period did not know the right thing to do, and so marriage contracts may not have been transacted possibly because those people were not people of the book prior to the appearance of the Prophet Muhammad (PBUH); they had probably married without a witness or without documentation in writing.

Previously, we have spoken about the need of a witness in the marriage contract. This is because as human beings, we are more likely to accept the obligation of the witness in validating a marriage contract whilst we also depend on the hadith of the Prophet Muhammad (PBUH) (No marriage except with the existence of a guardian and two trusted witnesses). In this study, we argue that the reason why Prophet Muhammad (PBUH) had said, 'No marriage except with the existence of a guardian, and two trusted witnesses' was meant to be an obligation to validate the marriage contract with a witness. Nonetheless, Prophet Muhammad (PBUH) did not mention the word, writing in the hadith. In this study, we also argue that the reason for this is because it was meant to make the Muslims 'live more conveniently since they did not have the ability to read nor write'. ${ }^{46}$ It appears that majority of the Islamic jurisprudence had prioritized the witness in the first position, among other means of showing

44 Al-Qāsimī, Muḥammad Jamāl al-Dīn bin Muḥammad Sa‘īì bin Qāsim al-Hallāq, Maḥāsin al-Ta'wīl, vol. 4, 96.

45 Abū al-Fidā’, Ismā‘̄îl Ḥaqqī bin Muștafāa al-Istanbūlī al-Ḥanafĩ al-Khalūtī, Rūh al-Bayān, vol. 2, 374.

46 'Ārif 'Alī 'Ārif al-Qaradaghī, 'Silsilah Buhūth al-Fiqhiyyah fĩ al-Qaḍāyā alMu'āsirah,' 38. 
proof even though Islamic laws had considered the written evidence to be one of the strongest evidence of proof. This is because the writing reliance had been rather limited during the period of the Islamic jurisprudence. Besides the guarantees which the Islamic legislators kept for testimony, it was apparent that during that era, the judges involved would also be familiar with the majority of the community; these judges would be able to recognize the sincerity of each one of the members in the community, hence proof of evidence through witnesses can be quite credible. The only disadvantage of this is the fear of the witnesses losing their memory, which time may impact on gradually.

As was also noted, during the era of the Islamic jurisprudence, the Arabs were noted for their honesty and credibility in telling the truth, hence witnesses as proof of evidence for marriage contracts were well accepted. Nonetheless, with the expansion of the Arab communities, and the possibility of people lying and creating forgery, the confidence in witnesses' testimony as proof of testimony dwindled, tainted by the various aspects of human behavior. Hence, the proof of writing gained more credence, carried more recognition and had a higher status. ${ }^{47}$ Evidence of proof was no longer confined to just the text of the hadith or in oral forms only, but also in the include of causes. Not a religion of formalities, especially in terms of transactions and the changing customs, the formalities of Islam also changes with the varied habits and customs of the people. According to the rule, the decisions made for acceptance of proof of evidence for marriage contracts began to change.

Since marriage contracts were not really supposed to be in deadlocks, it became obvious that documenting marriage contracts in writing was compulsory, as noted in all heavenly laws although statutory laws came to document marriage contracts in writing. The beginning of this was with Adam (PBUH), then noted in the manuscripts of Ibrahim, which Hammurabi mentioned in his obelisk. This was further noted in the Torah and the Gospel, after the 600-years of apostles' interruption, when illiteracy had increased. After the arrival of the Prophet Muhammad (PBUH), all Muslims learned to read and write, and the illiteracy that had prevailed was then significantly reduced. Thus began a time when Muslims began documenting their marriage contracts in writing and in attesting.

47 'Abbās al-'Abudī, Sharh Ahkē̄m Qānūn al-Ithbāt al- 'Iraqū ('Iraq: al-Maktabah alWațāniyyah, 1997), 196, 197. 


\section{BEGINNING OF THE DOCUMENTATION OF MARRIAGE CONTRACTS IN WRITING IN THE ISLAMIC SHARIAH}

The writing of marriage contracts was not something new, neither was it incidental since most modern scholars believed that they had existed since the existence of mankind with the first marriage contract being legislated by Allah Almighty for Adam and Eve, witnessed by the angels and all the people. This was noted in the verse of the al-Qur'ān:

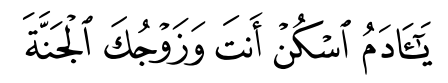

"And We said to Adam: "Both you and your spouse live in the Garden..."

(Surah al-Baqarah, 2: 35)

Allah Almighty ordered the writing of marriage contracts in the Torah and the Gospel, and this was also adopted by the old statutory laws. Nonetheless, this was held back from practice until the arrival of Prophet Muhammad (PBUH), who created special rules for the marriage contract. This was in the form of a testimony on the marriage contract, and the presence of a guardian for the woman betrothed, hence the documentation of the marriage contract was collective.

At that time, no one denied the marriage contract because the society was being governed by faith and honesty. Thus, documentation of the marriage contracts had remained to be based on testimony of witnesses until the spread of writing occurred, and then acquired by people throughout. Apparently, the Muslims began documenting marriage contracts in writing before the beginning of the Fatimid era (358 AH / $567 \mathrm{AH})$. Historians had revealed that the collection of marriage contracts were established through writing on leather, with the oldest dating back to year $233 \mathrm{AH}$. This was recorded on a red leather length $48.5 * 23 \mathrm{~cm}$.

There were also marriage contracts written on papyrus dating back to 259 AH. ${ }^{48}$ Although there may be older marriage contracts, these have not been discovered yet. Of those marriage contracts discovered and documented in writing, it was revealed that certain details were included, such as husband's name, wife's name, date of the contract, amount of the dowry, consent of the guardian, and the presence of witnesses. It appears that the judges were the

48 Adolf Jrohman, Awrāq al-Bard̄̄ al-'Arabiyyah, al-Sifr al-Awwal (Qāhirah: Maṭba'ah Dār al-Kutub al-Mișriyyah, 1934), 75. 
people who concluded and documented these marriage contracts. ${ }^{49}$ In the Fatimid era, the judges' responsibilities increased, and marriage contracts became prolonged during disputes. The idea of a judge's authorization to compel one of the clerics to conclude such contracts and document on his behalf then became the fashion. This was achieved with a permit granted for each marriage contract, and the cleric gets delegation for each marriage contract. As the marriage contracts increased, the judges also began delegating fifteen mandates to the clerics. Thus, the work of the judges changed when the marriage contracts began to increase. Once the clerics completed these fifteen contract marriages, the judges would delegate the clerics another fifteen. Thus, we find that the clerics in some of the countries operating the authorized legal system had a record of fifteen marriage contracts.

\section{WRITING OF MARRIAGE CONTRACTS ACCORDING TO THE IRAQI LAWS}

The Shariah Courts in Iraq were formed when Iraq was under the Ottoman rule from 1523 to 1918 . The Shariah court ruling was according to the first regulation of the Islamic jurisprudence on the Hanafi madhhab that is, Ordinances of Islam where the last one was issued in $1882 \mathrm{AD} .{ }^{50}$ The personal status court was also established, and the first regulation was issued for personal cases. It was called the Book of Shariah rulings for personal cases on the madhhab of Abū Hanifa al-Nu'man (Muhammad Qadri Pasha). ${ }^{51}$

This law does not include any reference to the writing or documenting of marriage contracts with judges or others, as confirmed in Chapter VII by the jurist, on the dowry conflict, and spouses' denial among them. If the regulation contained a text in the writing of a marriage contract, then the regulation should refer to the written evidence. However, the cases of marriage denials

49 Al-Subā‘̄i, Aḥmad bin 'Abd al-Jabbār, al-Ma'dhūn al-Shar '̄i wa Wajabātuh alShar'iyyah wa al-Nizāmiyyah fì al-Mamlakah al-'Arabiyyah al-Sa'ūdiyyah (Riyāḍ: Majallah al-'Adliyyah, 2003), 19.

50 Midhat al-Mạ̣mūd, al-Qaḍ̄' fì al- 'Irāq ('Iraq: Maktabah al-Sanhūrī, 2011), 11.

51 Yahtawī kitāb al-Aḥkām al-Sharī'ah fī al-Aḥwāl al-Shakhșiyyah kul ma yata'allaq bi al-Aḥwāl al-Shakhṣiyyah masughata bi Shakl taknin wa Muratabat 'ala Shakl Abwāb wa akhtassa al-ban 'ala 'ashr minha 'ala ithbāt al-nikāḥ wa al-iqrār bih: Muḥammad Qadrī Bāshā, al-Aḥkām al-Shar 'iyyah fì Qānūn al-Aḥwāl alShakhșiyyah (Bayrūt, Lubnān: Dār Ibn Hazm, 2007). 
and dowry denials increased so much that the Ottoman state issued another regulation called family rights on 25 October $1917 . .^{52}$

Article (23) stated that during the contract, the judge or his deputy who was authorized to issue a specific paper permit would visit the residence of one of the spouses. The judge or his deputy could organize and document the contract papers.

After the British occupation of Iraq, the statement court's formation law was issued on 28 December 1917. In Article (14), it was stated that the civil courts have to apply Ottoman laws that were in place during the occupation of Baghdad. The procedure of the marriage contracts was to be written and documented by a judge or his deputy. This is in spite of the fact that there was no legal rule to impose or punish those who did not succeed in registering a marriage contract. After the revolution of 17 July 1958, a committee was conducted by the Ministry of Justice, and the first personal status law of Iraq number (188) was issued in 1959. It was mentioned in Article (10) that the procedure for registration of the marriage contract was to be followed as such. First, the marriage contract could be registered in the competent court without a fee in a special register according to the following condition - The marriage contract registration was not compulsory, as was stated by the legislator, but it was without a text which was mandatory. After the issuance of marriage contracts surged outside Iraqi courts, with several cases of marriage denials or marriages to a second wife without the permission of the courts, the Iraqi legislator then issued the second amendment to the personal status law No. 188 of 1959. In its place was Article No. (21) issued in 1978 where an additional paragraph (5) was added to the text of Article (10) which involved a legal penalty for anyone who held his marriage outside the courts as noted below:

'A penalty of imprisonment for a period of not less than six months, and not more than one year, or a fine of not less than three hundred dinars, and not more than one thousand dinars, were imposed on each man who married outside the court, and imprisonment for a period of not less than three years, and not more than five years if the marriage was outside the court and with another marriage'.

52 Lajnah Mukawanah min 'Iddah 'Ulamā' wa Fuqahā' fī al-Khilāfah al'Uthmāniyyah, Majallah al-Aḥkām al-'Adliyyah, taḥīi Najib Hawāwini (n.p.: Nūr Muḥammad Kārakhanah Tijārat Kutub, Ārām Bagh, Karātshi, duna Sanah Nashr 1942), 14. 
This text has had a significant effect in reducing foreign marriage contracts, prior to the occupation of Iraq by US forces in 2003. However, foreign marriage contracts have become considerably obvious in spite of the fact that this legal text was introduced in the Iraqi Personal Status law, after US occupation in 2003. It occurred at the time the security situations deteriorated, and the weakness of the rule of law and the control of religious parties among the pillars of the Iraqi state became worse. These factors had a major role in causing the spread of marriage contracts outside the courts which had insisted that marriage contract registrations be under the jurisprudence of the era/ nawāzil al-'așr. Some clerics had thought that marriage contract registrations are a heresy.

\section{CONCLUSION AND RECOMMENDATIONS}

To sum up, the documenting of the marriage contract is not a jurisprudence of conception. It does not need the contemporary jurisprudence because the Islamic law has been dealing with the marriage contract since the beginning of mankind on the face of earth, as ordered by the Allah Almighty. As noted in all heavenly books, there were strong evidence linking the marriage contracts with the need of a testimony. However, this was not applied during the period of the Prophet Muhammad (PBUH) due to the reasons mentioned above. Nonetheless, this should not be taken as proof of evidence that marriage contracts were not considered during that era. Moreover, the Arabs of alJahiliyah during the era of Islam had not acquired the ability to read and write, hence this was not mentioned in the al-Qur'ān although the Holy al-Qur'ān provides some general judgments. The particulars and details, were however, explained by the hadith and the jurisprudential views. This had also caused the difference in opinions among the researchers examining marriage contract testimonies. For instance, the Jaafari madhhab did not rely on the hadith of the prophet which states 'No marriage except with the existence of a guardian and two trusted witnesses'. The following verse is thus interpreted as:

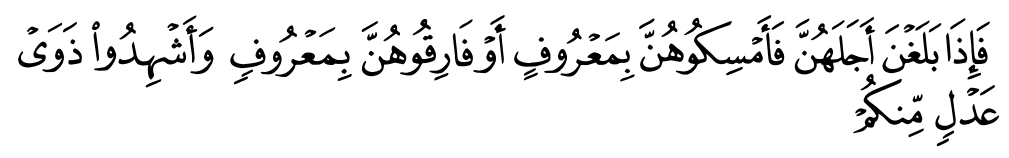

"When they have reached their appointed time, then either keep them lawfully or let them go honorably; but have two witnesses from among you..."

(Surah al-Ṭalāq, 65: 2) 
Despite the above outcomes, witness testimonies could also be used in divorce even in marriages without marriage contracts. This study thus recommends that the marriage contracts should be written and documented by the designated party, and according to the Positional law which is linked with testimonies. In any case, the lack of this written document in the marriage contract does not invalidate the contract.

\section{REFERENCES}

'Abbās al-'Abūdī, Sharh Ahkām Qānūn al-Ithbāt al- 'Irāqī ('Iraq: al-Maktabah al-Wațāniyyah, 1997).

'Abd al-'Azīz al-Muhammad al-Salman, Mukhtașșar al-Așilah wa al-Ajwibah al- 'Ușūliyyah 'ala al- 'Aqīdah al-Wașațiyyah (n.p.: Dūn al-Dikr Makān al-Tibā', 1997).

'Ārif 'Alī 'Ārif al-Qaradaghī, 'Silsilah Buhūth al-Fiqhiyyah fī al-Qaḍāyā alMu'āsirah,' Masā’il Shar 'iyyah fì Qadāyā al-Mar'ah (Malaysia: alJamī'ah al-Islāmiyyah al-'Alāmiyyah, 2010).

Al-A'ẓamī, Muḥammad Ṭaha Muḥammad wa Aḥmad Majīd Hamīd, Qānūn Hammurābī Dirāsah Muqārinah (Iraq,Majallah al-Najaf al-Ashraf, al'Adad al-Awwal 2003

Abī Bakr 'Uthmān Muḥammad Shaṭa' al-Dimyatī al-Bakrī, I'ānah al-Ṭālibìn 'ala Hal Alfāz Fath al-Mu'in, vol. 3 (Bayrūt: Dār al-Fikr li Ṭaba'ah wa al-Nashr wa al-Tawzī‘, 1997).

Abī Muḥammad 'Abd Allāh Ibn Aḥmad Ibn Muḥammad Ibn Qudāmah alMaqdisī, al-Kāfì fì al-Fiqh al-Imām Aḥmad, vol. 4 (Bayrūt: Dār alKutub al-'Ilmiyyah, 1994).

Abū al-Fidā’, Ismā'īl Ḥaqqī bin Mușțafā al-Istanbūlī al-Hanafì al-Khalūtī, Rūh al-Bayān (Bayrūt: Dār al-Fikr, n.d.).

Abū Dāwud, Sunan Abū Dāwud, taḥqīq Muḥammad Maḥy al-Dīn 'Abd alHamīd (Bayrūt: al-Maktabah al-'Așriyyah, Duna Dhakara Sanah alNashr, 1965).

Abū Hafs Sirāj al-Dīn 'Umar bin 'Ali bin 'Ādil al-Hanbalī al-Dimashqī alNu'mān̄i, Allubāb fì 'Ulum al-Kitāb, taḥīiq al-Shaykh 'Ādil Aḥmad 'Abd al-Mawjūd wa al-Shaykh 'Alī Muhammad Mu'awwad (Bayrūt: Dār al-Kutub al-'Ilmiyyah, 1998).

Adolf Jrohman, Awrāq al-Bard̄̄ al-'Arabiyyah, al-Sifr al-Awwal (Qāhirah: Maṭba'ah Dār al-Kutub al-Mișriyyah, 1934). 
Aḥmad al-Shamī, 'al-Tațawwur al-Tarīkh li 'Uqūd al-Zawāj fī al-Islām,' (Ph.D Thesis, Kulliyyah al-Ādab, Jamī'ah al-Zaqaziq, 1982).

Aḥmad Hāshim Ibrāhīm al-'Aț̣ār, 'Huqūq al-Mar'ah fī al-Sharā'i' al'Irāqiyyah al-Qadīmah,' Silsilah Thaqāfiyyah Shahriyyah tașdur 'an (Baghdād: Dār al-Shu'ūn al-Thaqāfiyyah al-'Āmmah, 2010).

Al-Andalūsī Muḥammad bin Yūsuf Abū Hayyan, Tafsīr al-Baḥr al-Muḥịt, taḥqīq al-Shaykh 'Adīl Aḥmad 'Abd al-Mawjūd al-Shaykh 'Alī Muhammad Mu'awwad (Bayrūt, Lubnan: Dār al-Kutub al-'Ilmiyyah, 2001).

Al-Bayhaq̄ī, al-Sunan al-Kubrā, taḥqīq Muḥammad 'Abd al-Qādir 'Ațā (Bayrūt: Dār al-Kutub al-'Ilmiyyah, 2003).

Al-Bukhārī, Șaḥīh al-Bukhārī, taḥqīq Muḥammad Zuhayr Ibn Nāṣir al-Nāṣir (Dār Ṭūq al-Najāh, 1422H).

Al-Dubyān, Abū 'Umar Dubyān bin Muḥammad, al-Mu' āmalah al-Māliyyah Așālah wa Mu'āsirah, vol. 18 (Riyāọ: Maktabah al-Mālik Fahd alWațāniyyah, 1432AH).

Al-Hafī, Muḥammad al-Amīn bin 'Abd Allāh al-Aramī al-'Alawī al-Hararī, Muraja`at, Hashim Muhammad 'Alī bin Husayn Mahdī, Tafsìr Hada’iq al-Rūḥ wa al-Rayḥ̄an fì Rawābi ' 'Ulūm al-Qur'ān (Bayrūt, Lubnan: Dār Tawq al-Najah, 2001).

Ibn 'Āshūr, Muhammad al-Ṭāhir bin Muhammad al-Ṭahir, al-Tahrīr wa alTanwīr (Tunisiyah: Dār Sạ̣nūn li Nashr wa al-Tawzī‘, 1997).

Ibn Abī Zamānīn al-Malikī, Abū 'Abd Allāh Muḥammad bin 'Abd Allāh bin 'Īsā bin Muḥammad al-Marrī, Tafsīr al-Qur'ān al- 'Azīz li Ibn Ab̄̄ Zamānīn, vol. 2, taḥī̄ Abū 'Abd Allāh Husayn bin 'Ukāshah (Qāhirah, Miṣr: Muḥammad bin Mușțafā al-Kanz al-Fārūq al-Hadīthah, 2002).

Ibn al-Āthīr, Majd al-Dīn Abū al-Sa'ādāt al-Mubārak bin Muhammad bin al-Āthīr al-Jazarī, Jāmi' al- 'Ușūl fì Aḥ̂̄dìth al-Rasūl, tahqīq 'Abd alQādir al-Arna'ūṭ al-Tatimmah, taḥ̂īq Bashīr Muhammad 'Uyūn (n.p.: Maktabah al-Halwān̄i, Mațba'ah al-Malāḥ, Maktabah Dār al-Bayān, 1972).

Ibrāhīm Zakī Khurshīd, Aḥmad al-Shantanāwī, 'Abd al-Ḥamīd Yūnus, Mūjaz Dà'irah al-Ma 'ārif al-Islāmiyyah, tarjamah Nukhbah min al-Asātidhah al-Jāmi 'àt al-Mișriyyah wa al-'Arabiyyah, al-Murāja 'ah wa al-Ishrāf al-'Ilmī, Hassan Habashī, 'Abd al-Rahmān 'Abd Allāh al-Shaykh, Muḥammad 'Annān̄̄ (Markaz al-Shāriqah li al-Ibdā' al-Fikrī, 1998).

Al-Kasān̄̄, Muḥammad bin 'Abd Allāh, Qaṣaṣ al-Anbiyā', taṣḥ̣̣̄ Isḥāq bin Saul Izinberg, vol. 1 (Leiden: Mațba'ah Barbil, 1922). 
Lajnah Mukawanah min 'Iddah 'Ulamā' wa Fuqahā' fī al-Khilāfah al'Uthmāniyyah, Majallah al-Ahkēm al- 'Adliyyah, taḥqīq Najib Hawāwini (n.p.: Nūr Muḥammad Kārakhanah Tijārat Kutub, Ārām Bagh, Karātshi, duna Sanah Nashr 1942).

Al-Makkī, 'Abd al-Mālik bin Husayn bin 'Abd al-Mālik al-'Ișāmī, Samṭ alNujūm al- 'Awālì fì Anbā' al-Awā' 'il wa al-Tawālì al-Mutawaffā, taḥqīq 'Ādil Aḥmad 'Abd al-Mawjūd, 'Alī Muḥammad Mu'awwad (Bayrūt: Dār al-Kutub al-'Ilmiyyah, 1998).

Midhat al-Maḥmūd, al-Qad̄̄' fì al- 'Irāq ('Iraq: Maktabah al-Sanhūrī, 2011).

Millar Burrows, Louis M. Epstein, 'Marriage Laws in the Bible and the Talmud,' Journal of Near Eastern Studies, vol. 3/2 (1944).

Muhammad Qadrī Bāshā, al-Aḥkām al-Shar 'iyyah fì Qānūn al-Aḥwāl alShakhșiyyah (Bayrūt, Lubnān: Dār Ibn Hazm, 2007).

Muḥammad Shukrī Surūr, Niẓām al-Zawāj fì al-Sharā'i ' al-Yahūdiyyah wa al-Masīhiyyah (Miṣr: Dār al-Fikr al-‘Arab̄̄, 1979).

Al-Naysābūrī, Nizāàm al-Dīn al-Ḥasan bin Muhammad bin Husayn al-Qamī, Gharā'ib al-Qur'ān wa Raghā'ib al-Furqān (Bayrūt, Lubnān: Dār alKutub al-'Ilmiyyah, 1996).

Al-Qāsimī, Muḥammad Jamāl al-Dīn bin Muhammad Sa'īd bin Qāsim alHallāq, Maḥāsin al-Ta'wīl, taḥqīq Muḥammad Bāsil 'Uyūn al-Sūd (Bayrūt: Dār al-Kutub al-'Ilmiyyah, 1418H).

Radinah Muḥammad Rida Majīd, al-Ahwā̄l al-Shakhșiyyah fì al-Qawānīn al-'Irāqiyyah al-Qadìmah ('Iraq: Majallah Markaz Dirāsah al-Kufah, 2011).

Șabīh Maskūnī, Tārīkh al-Qānūn al-'Irāqī al-Qadīm (Baghdād: Maṭba'ah Shafìq, 1971).

Al-Sarakhsī, al-Mabsūt (Bayrūt: Dār al-Fikr li al-Ṭabā'ah wa al-Nashr wa alTawzī', 2000).

Al-Shaybān̄̄, Abū 'Abd Allāh Aḥmad bin Muḥammad bin Hanbal bin Hilāl bin Asad, Musnad al-Imām Ahmad bin Hanbal, ed. Shu'ayb al-Arna'ūt (n.p.: Mu'asasah al-Risālah, 2001).

Subā'̄̄, Aḥmad bin 'Abd al-Jabbār, al-Ma'dhūn al-Shar'ī wa Wajabātuh al-Shar'iyyah wa al-Nizāmiyyah fi al-Mamlakah al-'Arabiyyah alSa 'üdiyyah (Riyāḍ: Majallah al-'Adliyyah, 2003).

Ṭaha Baqir, Muqaddimah fì Tārīkh al-Hadarāt al-Qadīmah, vol. 1 (Baghdād: Sharīkah al-Tijārah wa al-Tibā'ah, 1965). 
Al-Tha'labī, Abū Zayd 'Abd al-Raḥmān bin Muhammad bin Makhlūf, alJawāhir al-Hisān fì Tafsīr al-Qur'ān, tạ̣qīq al-Shaykh Muḥammad 'Alī Mu'awad wa al-Shaykh 'Ādil Aḥmad 'Abd al-Mawjūd (Bayrūt, Lubnān: Dār Ihyā’ al-Turāth al-'Arabī, 1418H).

Thalmā Sityān 'Aqrāwī, al-Mar'ah: Dawruhā wa Makānatuha fì Haḍārah Wādī al-Rāfidayn (al-Baghdād: Dār al-Hurriyyah li al-Tibā'ah, 1978).

Al-Ya'murī, Ibrāhīm bin 'Alī bin Muhammad bin Farhūn, Burhān al-Dīn, Tabșìrah al-Hukkām fì 'Ușūl al- 'Aqdiyyah wa Manāhị al-Aḥkām, vol. 1 (Mișr: Maktabah al-Kulliyyāt al-Azhariyah, 1986).

Zirar, Malikah Yūsuf, Mawsū'ah al-Zawāj wa al- 'Alaqal al-Zawjiyyah fì alIslām wa al-Sharā'i ‘ al-Ukhra al-Muqāranah, vol. 1 (Qāhirah, Miṣr: Dār al-Ghurayb li al-Ṭaba'ah, 2000).

Al-Zuḥaylī, Muḥammad Muștafā, Wasā ’il al-Ithbāt (Dimashq: Dār al-Bayān, 1982). 